UDC 32.019 .51

Submitted: 12.02 .2016

LBC 63.3

Accepted: 30.08 .2016

\title{
"TOP" INITIATIVES AND TRANSFORMATION OF PUBLIC ASSOCIATIONS OF RUSSIA IN THE SECOND HALF OF THE 1980S
}

\author{
Elena N. Shuyakova \\ Board of the "Russian community" regional public organization for the protection and realization of civil, \\ economic and social rights, Rostov-on-Don, Russian Federation
}

\begin{abstract}
Public initiative has always been a landmark in the processes of national development. Another thing is that the format of its implementation tends to vary under the influence of external factors. The present study is devoted to one of these cases. The author carries out the analysis of legal frameworks relating to the functioning of voluntary associations in Russia, and attempts to overcome the longstanding historiography tradition and to look differently at structuring civil society processes. That is, not through the prism of the generally accepted "greater publicity and freedom", but through the specific initiatives of the public authorities and their vector vision developments within Soviet society. Emphasis is placed on the degree of autonomy of the public association and its change in this period, focusing on the implementation of public tasks of national importance. Special attention is paid to the interaction of public associations with each other and with the authorities. The author defines the mechanisms for building such relations and prospects for their further development; identifies the implications of initiatives from this time for both the public and the authorities. In general, the study demonstrated the progress made in implementing the so-called "managed" democracy and the formation of a new, not inherent in the previous practice, model of civil society. This model is characterized by the gap in the interaction of authorities and public institutions, the transformation of the role and place in society of such structures as assembly of citizens, trade unions, people's control bodies and so on.
\end{abstract}

Key words: public initiative, "top" initiatives, bodies of public self-activity, public associations, interaction, civil society.

УДК 32.019 .51

Дата поступления статьи: 12.02.2016

ББК 63.3

Дата принятия статьи: 30.08.2016

\section{ИНИЦИАТИВЫ «СВЕРХУ» И ТРАНСФОРМАЦИЯ ОБЩЕСТВЕННЫХ ОБЪЕДИНЕНИЙ СТРАНЫ ВО ВТОРОЙ ПОЛОВИНЕ 1980-х ГОДОВ}

\author{
Елена Николаевна Шуякова \\ Региональная общественная организация по защите и реализации гражданских, \\ экономических и социальных прав «Русская община», г. Ростов-на-Дону, Российская Федерация
}

\footnotetext{
Аннотация. Общественная инициатива всегда была и остается знаковым явлением в процессах общегосударственного значения. Другое дело, что формат ее реализации имеет тенденцию меняться, в том числе и под воздействием внешних факторов. Одному из таких случаев и посвящено предлагаемое иссле-

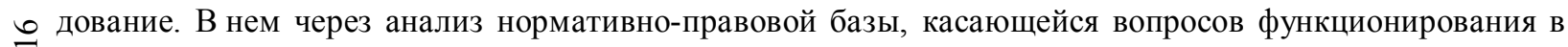
¿ㄱ России общественных объединений, предпринимается попытка преодолеть устоявшуюся историографическую традицию и по-иному посмотреть на процессы структуризации гражданского общества во второй половине 1980-х гг, то есть не сквозь общепринятую призму «расширения гласности и свободы», а через законодательные инициативы органов государственной власти и их вектор видения развития событий внутри советского общества. Акцент сделан на степени самостоятельности общественного объединения и ее варьировании в этот период, нацеленности общественности страны на реализацию задач общегосударственной важности. Уде() лено внимание вопросам взаимодействия общественных объединений друг с другом и непосредственно с
} 
органами власти. Определяются механизмы выстраивания таких отношений и перспективы их дальнейшего развития. Выявляются последствия инициатив «сверху» этого времени как для общественников, так и для органов власти. В целом материалы исследования демонстрируют ход реализации так называемой «управляемой» демократии и формирование новой, не свойственной предыдущей практике, модели гражданского общества. Ее отличительной чертой стал разрыв взаимодействия власти и общественных институтов, трансформация места и роли в жизни общества таких структур, как сход граждан, профсоюзы, органы народного контроля и т. д.

Ключевые слова: общественная инициатива, инициативы «сверху», органы общественной самодеятельности, общественные объединения, взаимодействие, гражданское общество.

С середины 1980-х гг. по праву можно говорить об очередном новом этапе функционирования общественных объединений в России, что было вызвано внедрением в общественно-политическую жизнь новых чертежей их функционирования, отличных от предыдущих лет. В целом весь этот период - вторая половина 1980-х гг. был ознаменован достаточно большим количеством властных решений относительно места и роли в жизни страны общественной инициативы. Под последней следует понимать не только генерацию населением страны своих предложений по модернизации жизни общества, а и непосредственное его участие в их практическом воплощении и достижении общественно-значимых результатов, в том числе посредством деятельности в рамках общественного объединения. В прямом смысле слова во второй половине 1980-х гг. осуществлялось становление принципиально новых условий соучастия населения в управлении государством, решении его насущных задач. Та скорость, с которой это осуществлялось, а также отсутствие турбулентного переходного периода наталкивают на мысль, что делалось это по готовым калькам. Вероятно, в силу этой причины и произошел с первого раза незаметный эксперимент в нашей стране по модернизации социально-политических ориентиров советского общества и, соответственно, трансформации общественной инициативы. Ведь даже среди исследователей уже долгое время превалирует установка на то, что вторая половина 1980-х гг. была временем ее расцвета. Однако это касается в большей степени неформальных общественных объединений, массово возникающих в этот период, а ведь параллельно с этим с подачи органов государственной власти шли процессы и относительно той общественной инициативы, которая зарекомендовала себя в предыдущий период и функционировала на вполне легальной основе. Ученые-обществоведы смотрят на эти структурные образования с определенной долей скепсиса [19]. То, что руководство страны всячески пыталось нивелировать роль данных общественных структур, уже свидетельствует об их значимости в жизни общества. Суть этого процесса в полной мере позволяет понять анализ нормативно-правовых актов, касающихся реализации именно этого вида общественной инициативы периода правления М.С. Горбачева, а именно увидеть, что общественная инициатива в том виде, в каком она сложилась в предыдущий период развития советского общества, в это время, по сути, «сворачивала» свою деятельность.

Согласно Указу «Об утверждении Положения об общих собраниях, сходах граждан по месту их жительства в РСФСР», принятому в августе 1985 г., Президиум Верховного Совета РСФСР лишил самих граждан права инициировать проведение своего же схода. Это мог сделать лишь исполком соответствующего Совета народных депутатов. Это означает, что органы государственной власти попытались упрочить собственные позиции и лишить самостоятельности общественную инициативу, в среду которой вносили очередную «ложку дегтя», а именно усиливали диспропорцию представительства общественных образований в процессе их соучастия в управлении государственными и общественными делами. В то время как ранее ставка делалась на внутреннюю сплоченность общественной структуры и ее массовый по количественному составу характер, то теперь под массовостью стала пониматься множественность общественных образований. На практике это проявилось в падении качественных показателей работы общественных образований: 
«О какой эффективности воспитательной работы может идти речь, когда, например, в Железнодорожном районе насчитывается 60 советов микрорайонов. Райкому КПСС неоднократно указывалось на недостатки такого дробления. В результате Райком КПСС упустил из поля зрения работу советов микрорайонов, оказался бессилен в осуществлении влияния и контроля за их работой» [1, л. 9]. Причем поощряться «сверху» стало не столько формирование принципиально новых структур, сколько деление некогда единой структуры на ряд дополнительных образований, как это было со сходами граждан. Выделение из их числа новых дополнительных структур в виде сельских, уличных и квартальных комитетов фиксировалось отдельным правовым актом Президиума Верховного Совета РСФСР от 3 сентября 1985 г. - Указом «Об утверждении Положения об общественных сельских, уличных, квартальных комитетах в населенных пунктах РСФСР». Согласно документу данные органы общественной самодеятельности, избираемые на общих собраниях (сходах) граждан, признавались объединением, призванным содействовать органам власти в «привлечении граждан к участию в решении вопросов местного и общегосударственного значения» [17]. Какой-либо другой более конкретной и содержательно насыщенной стратегической цели перед данными образованиями поставлено не было. Перечень их направлений деятельности был настольно широк, что перекликался с целевой заданностью и пожарного общества, и общества по охране памятников истории и культуры, и общества по охране природы. Отсюда возникает весьма недвусмысленный вопрос: понятен мотив создания сходов граждан в 1927 г. - решение общих вопросов определенной части населения, и совсем он не понятен у сельских, уличных и квартальных комитетов, избираемых из числа участников схода граждан. Имеется в виду отсутствие у сельских, уличных и квартальных комитетов стратегической цели, измеряемой конкретными показателями результативности. Более того, возникает некоторое противоречие в действиях одного и другого, когда общее собрание (сход) граждан созывается для решения своих насущных вопросов, в том числе пересекающихся с противоречивой дея- тельностью властных структур, одновременно с чем формирует вторую структуру, призванную «служить» этим самым властным структурам. Следовательно, властью создавались условия для того, чтобы на общем собрании (сходе) граждан присутствовали граждане, отстаивающие непосредственно ее позицию. Так, секретарем Ростовского горкома КПСС Л.Г. Каймакчи в 1986 г. фиксировалось: «В районах повсеместно создаются советы микрорайонов, в которые входят представители партийных, профсоюзных, комсомольских организаций... руководители депутатских групп...» [1]. По сути, складывалась модель, когда общее собрание (сход) граждан находилось под контролем людей, верных власти [3, с. 48]. Этим власть пыталась контролировать общественное мнение и воздействовать на принятие общим собранием (сходом) граждан решения с учетом политики органов государственной власти. В сущности, это было прямое вмешательство власти во внутреннюю деятельность органа общественной самодеятельности. Учитывая «тонкость» данной процедуры, ее по праву можно назвать своеобразной политической технологией, когда манипулирование сознанием граждан в интересах власти она осуществляла их же «руками». К подобным выводам приходит и исследователь Н.В. Руденко, отмечая, что по итогам реформы «сверху» в отношении института собрания (схода) граждан он не стал обеспечивать «реального участия граждан в управлении посредством самостоятельного принятия ими публично-властных решений. Общие собрания (сходы) граждан... являлись придатком советов с крайне ограниченной сферой собственной компетенции» $[16$, c. 383].

Достаточно резко в жизнь советского общества входит практика по созданию общественных объединений, чей ареал деятельности ограничивался либо рамками отдельного учреждения, предприятия, организации, как в случае с комиссиями по борьбе с пьянством, утверждение которых произошло 1 октября 1985 г. посредством принятия Президиумом Верховного Совета РСФСР соответствующего указа, либо границами отдельного ведомства, например, Министерства внутренних дел СССР для Совета ветеранов. 


\section{ОТЕЧЕСТВЕННАЯ ИСТОРИЯ}

Достаточно призрачной становилась и связь общественных объединений с органами государственной власти. Из нормативноправового лексикона законодателя исчезло словосочетание «подотчетность» общественного образования тому или иному органу государственной власти. На смену приходит формулировка типа: «Совет ветеранов периодически информирует руководство Министерства, Политическое управление и Партком МВД СССР о своей работе» [14].

Уже с 1986 г. Совет Министров СССР начинает уделять пристальное внимание вопросам увеличения финансовой составляющей в деятельности общественных объединений. Одними из первых в этом ряду стали творческие союзы граждан (писателей, кинематографистов, композиторов, театральных деятелей, художников), для которых теперь предусматривалось увеличение выделения значительных сумм на расширение сферы их деятельности. Так, Постановлением Совета Министров СССР было учреждено Всесоюзное музыкальное общество, которое свою деятельность призвано было осуществлять бесконтрольно со стороны властных структур. Последние, напротив, обязались содействовать Обществу в реализации его задач, среди которых было «всемерно содействовать развитию и пропаганде музыкального искусства в СССР, расширению участия музыкальной общественности и любителей музыки в дальнейшем развитии советской музыкальной культуры» [5]. И в первую очередь Государственный комитет СССР по труду и социальным вопросам наряду с ВЦСПС и Министерством финансов СССР должны были «определить штатную численность центрального аппарата Всесоюзного музыкального общества, его отделений и условия оплаты труда работников». Обществу также выделялось для размещения центрального аппарата здание «размером не менее $1400 \mathrm{~m}^{2} \ldots$ для легковых автомобилей «Волга»... а также один грузовой автомобиль» [5]. Совет Министров СССР устанавливал и нормативы отчислений от его предприятий, учреждений и организаций «30 процентов получаемых доходов... на содержание аппарата этого Общества и иные цели», тем самым формируя собственный фонд Общества и предоставляя право само- стоятельного им распоряжения. Причем все это должно было производиться в условиях его освобождения «от уплаты налогов, государственной пошлины и других видов сборов» [5].

Следом выходит в свет Постановление Совета Министров СССР и ЦК КПСС «Об улучшении условий деятельности творческих союзов СССР», которым предусматривалось создание собственных денежных фондов и у Союза кинематографистов СССР, и у Союза театральных деятелей СССР, и у Союза писателей СССР и т. д. Отчисления в данный фонд, например, Союза кинематографистов СССР производились в том числе «в размере одного процента от доходов проката всех видов кинофильмов на территории СССР... от доходов предприятий и имущества, принадлежащих Кинофонду СССР» [6]. Предусматривалось и их организационное укрупнение вплоть до введения штатных единиц с установлением им денежных окладов и введением дополнительной системы вознаграждений. Такое усиление присутствия денежного эквивалента в деятельности общественных организаций более наглядно демонстрирует Всесоюзное общество изобретателей и рационализаторов, отчисления в пользу которого со стороны предприятий, внедряющих их разработки, возросли от $0,3 \%$ (ставка 1958 г.) до $0,6 \%$ от суммы экономии в 1987 г. [7].

Такое повышенное внимание со стороны органов власти к финансовой составляющей творческих объединений, вероятно, было связано с необходимостью формирования в общественном сознании новых стереотипов мышления. Об этом, собственно, и свидетельствует пункт 13 Постановления Совета Министров СССР от 14 февраля 1987 г. № 213 «Об улучшении условий деятельности творческих союзов»: «Поручить Агентству печати "Новости" издавать по заказу и на средства Союза кинематографистов СССР книги, брошюры, буклеты по киноискусству на иностранных языках для распространения по каналам Союза кинематографистов СССР и Агентства» [6]. То есть при принятии решения о финансировании общественной деятельности, органами власти учитывался факт того, что общественники и особенно творческая интеллигенция имеют выход на большую целевую аудиторию. В 1990 г. коммерческая 
составляющая с подачи органов государственной власти была привнесена и в деятельность Союза учителей СССР, Союза ветеранов Афганистана, Союза фотохудожников СССР и др. [11; 12]. К решению подобного рода вопросов в деятельности общественных образований термином «обязать» привлекались соответствующие властные структуры.

Активно госорганами стало поощряться появление в стране принципиально новых организаций, которых отличало, во-первых, наличие в их деятельности зарубежных активов, во-вторых, главным мерилом эффективности их функционирования становились денежные ресурсы и как можно большее их внедрение в различные сферы жизни общества и, в-третьих, отсутствие сколько-нибудь внятного целеполагания. Таковыми структурами стали: Советский фонд милосердия и здоровья, образованный в октябре 1988 г., Советско-американский фонд «Культурная инициатива» и Международная неправительственная организация «Международный центр научной культуры - Всемирная лаборатория», возникшие в 1989 г., или Ассоциация писателей «Международный ПЕН-клуб», созданная в 1990 году. Широкая поддержка им предписывалась постановлениями Правительства страны: от денежного содержания штатных работников до обеспечения «автоматизированного обмена информацией с зарубежными сетями ЭВМ и банками данных через Национальный центр автоматизированного обмена информацией» [8]. Именно эти организации соответствующими постановлениями Совета Министров СССР призваны были сплотить общественные силы государства. Перечень направлений их деятельности, который декларировался соответствующими государственными документами, свидетельствует о том, что их деятельность была направлена на то, чтобы произвести подмену ценностей в жизни советского общества. От единого для всех стремления к построению социалистического общества жителям страны теперь предлагалось через участие в деятельности, к примеру, фонда «Культурная инициатива» посещать зарубежные страны «для прохождения стажировки и изучения опыта работы» [8], иметь стипендию, участвовать в выставках-продажах, аукционах, концертах и др. И это в условиях кон- статации соответствующим Постановлением Совета Министров СССР положения о том, что «Центральные и местные органы государственного управления не вправе устанавливать этому Отделению обязательные плановые задания» [9]. Таким образом, указанные общественные структуры органами власти наделялись полной свободой деятельности на территории России.

Размытости общественной инициативы способствовало и дальнейшее появление, правда, по чертежам предыдущего периода новых общественных образований, поскольку они с подачи органов государственной власти подменяли деятельность уже существующих. В 1989 г. создаются общественные структуры, по сути, дублирующие функции профсоюзов. Согласно Указу Президиума Верховного Совета СССР от 18 мая 1989 г. появились инспекции рабочего контроля профсоюзов. Вслед за этим в декабре этого же года последовала очередная инициатива Совета Министров СССР и ВЦСПС, учреждающая общественную организацию - Всесоюзную ассоциацию специалистов по охране труда, чьим главным предназначением становится обеспечение безопасности трудящихся на предприятии. Перечень функциональных обязанностей данных общественных образований фактически дублировал деятельность органов народного контроля, в состав которых по Закону СССР от 30 ноября 1979 г. «О народном контроле в СССР» входили и профсоюзы, то есть законодатель не пошел по пути совершенствования деятельности уже функционирующей общественной структуры, в данном случае органов народного контроля, объединяющих в своих рядах представителей достаточно широкого спектра общественных сил страны, а предпочел создание новой организации со значительно менее представительным контингентом.

Точно так же, как и в предыдущем случае, представители органов государственной власти поступили и в отношении образовательных учреждений страны, где учредили новую структуру в виде школьного самоуправления, чье функциональное предназначение пересекалось с деятельностью администраций учебных заведений. Наделение новой структуры правом принимать Устав школы, утверждать план раз- 
вития школы, устанавливать режим работы и прочее было ничем иным, как попыткой подменить новой общественной структурой официальные органы управления учебных заведений. Присутствие в «Положении о Совете средней общеобразовательной школы» установки на то, что данная структура призвана пресекать «любые попытки командно-административного диктата по отношению к коллективу школы, ограничения его самостоятельности» [13], свидетельствует о попытке противопоставить данный Совет партийным и государственным органам страны.

То, что в стране искусственно насаждались антагонистические настроения между властью и обществом, подтверждает и факт учреждения в 1989 г. Министерством народного образования РСФСР должности общественного инспектора по охране детства. Из одного только названия невольно всплывает понимание: поскольку требуется охрана, значит, есть от кого защищать. Что самое характерное для данной должности, так это установка на недопустимость совмещения данной общественной деятельности с другими, что «вырывало» человека из общих процессов жизни социума в целом и погружало в закрытое пространство, требующее от него приложения усилий в борьбе за интересы и права ребенка, содействия в сохранности его имущества. Утверждение на должность производил исполком соответствующего Совета народных депутатов, однако отчитываться инспектор должен был перед отделом народного образования с весьма прозрачной формулировкой: «периодически отчитываются о своей работе перед отделом народного образования» [4], в то время как перед выдвинувшим его коллективом уточнялось: не реже одного раза в год. Это означало не что иное, как то, что руководство страны фактически само же себя и уничтожало, разрушало «тот сук, на котором сидело», поскольку помимо разрыва связи власти с обществом умалялась роль самих органов власти в жизни общества и повышалась значимость общественности.

Окончательно все выше обозначенные процессы закрепил в советском обществе принятый в 1990 г. Закон СССР «Об общественных объединениях». Во-первых, под его действие не подпадали такие общественные об- разования, как товарищеский суд, народный контроль, домовые комитеты, что де-юре лишало их права считаться добровольными объединениями граждан, созданными для достижения единого целеполагания. Во-вторых, достаточно формальный характер приобретала деятельность самого общественного объединения, поскольку Законом отменялась практика предыдущих лет о фиксированном членстве, в частности вводилось: «Требование об указании в официальных документах на членство в том или ином общественном объединении не допускается» [2]. Данным положением порождалась безответственность члена общественного объединения, его формальное отношение как к собственной деятельности в его рядах, так, собственно, и к самому объединению. Все это могло спровоцировать ослабление связей внутри советского общества, разрозненность его граждан. Что касается непосредственно общественных объединений, так это малочисленность их внутреннего состава. И в-третьих, государству Законом отводилась роль «обеспеченца» реализации общественными объединениями «своих прав и законных интересов» [2]. Учитывая, что общественные объединения наделялись правом установления самостоятельных контактов с международными структурами, можно говорить о том, что «сверху» создавались все условия для интеграции российского общественного актива в международное сообщество.

Своим Распоряжением 1991 г. Президент СССР М.С. Горбачев «О Межреспубликанском исследовательском центре частного права» констатировал дальнейшую несостоятельность высших органов государственной власти в деле обеспечении развития государства, поскольку предписывал органам власти воспользоваться услугами новой консультативной организации. Одной из основных ее задач была «разработка рассчитанных на восприятие республиками моделей (проектов) единообразных положений частного права, рекомендаций по сближению и согласованию законодательства республик по вопросам организации рынка и обеспечения гражданских прав, а также предложений, направленных на взаимное согласование законодательства республик, Союза и Экономического сообщества с международно признанными принципами частного права» [15]. 
В целом начиная с 1990 г. органы государственной власти стали всячески потворствовать организации работы на территории страны международных организаций. Согласно постановлениям Совета Министров СССР органы государственной власти ставились в положение структур, призванных обслуживать интересы данных организаций. Так, в целях организации работы редакционно-издательского комплекса «Милосердие» Советского фонда милосердия и здоровья Министерству культуры СССР, Советам Министров союзных республик, министерствам и ведомствам СССР предписывалось оказывать издательству содействие «в отборе и фотографировании документов, раритетов художественных произведений, текстов, хранящихся в библиотеках и музеях, для их воспроизведения» [10]. Государственному комитету СССР по печати вменялось же содействовать в размещении на подведомственных предприятиях заказов издательства «Милосердие» на полиграфические работы и т. д.

Таким образом, модернизация общественно-политической сферы в период с 1985 по 1991 г. включительно происходила согласно двум направлениям. Первое было представлено инициативами органов власти, направленными на «реформирование» организационных форм деятельности общественных объединений. Это выразилось в переходе от массовых общественных объединений к их количественному множеству, более малочисленному по своему внутреннему составу. Это достигалось как за счет дробления некогда единых объединений, так и посредством учреждения принципиально новых по формату и характеру функционирования объединений граждан. Участие в их деятельности общественных деятелей, выступающих в качестве некоего «государственного агента», призванного представлять интересы провластных структур, позволяет говорить о несамостоятельности общественных объединений обозначенного периода.

Второе направление модернизации спектра общественных сил страны касалось сферы их взаимодействия с органами власти. Здесь основополагающим стала ориентация законотворцев на разграничение сфер ведения между органами власти и общественностью, чем и был спровоцирован разрыв их связей по совместному сотрудничеству. На смену этому в деятельность общественных объединений была привнесена независимость от органов власти. Одновременно с этим последние, согласно правовым решениям, перемещались в положение структур, призванных обеспечивать интересы общественных объединений. Этим нарушался принцип равного паритетного отношения власти и общества и разрывались их связи в следовании единому стратегическому курсу развития страны. Фактически ее гражданам предлагалось проявлять свою общественную инициативу независимо от целеполагания общегосударственного развития. Более того, поощрялось интегрирование общественных сил России в практику функционирования различного рода международных структур.

Итак, в результате обобщения пятилетней практики модернизации общественной инициативы властью с учетом нововведений принятого в 1990 г. Закона СССР «Об общественных объединениях» представляется возможным выявить ряд установок, позволяющих идентифицировать общественную инициативу следующим образом. Во-первых, ее стало характеризовать наличие множества подцелей в условиях отсутствия единого общегосударственного целеполагания. Во-вторых, отсюда в ее рядах проявились разрывы внутренних горизонтальных связей. В-третьих, малочисленность внутреннего состава и, наконец, в-четвертых, множественность общественных объединений. Основополагающим фактором следует признать обозначившуюся тенденцию к росту влияния общественных структур в разработке нового стратегического курса развития страны. Пагубный результат функционирования такого рода общественной инициативы в деле осуществления модернизационных процессов в стране очевиден, отчего нельзя не согласиться с В.В. Фортунатовым о том, что «Горбачевская модернизация в 1985-1991 гг. завершилась, по существу не начавшись» [18, с. 116].

\section{СПИСОК ЛИТЕРАТУРЫ}

1. Доклад секретаря горкома КПСС тов. Л.Г. Каймакчи на городском совещании, посвященном вопросам совершенствования работы по мес- 
ту жительства трудящихся // Центр документации новейшей истории Ростовской области. - Ф. 13. Оп. 20. - Д. 129.

2. Закон СССР «Об общественных объединениях» от 9 окт. 1990 г. № 1708-1. - Доступ из справ.правовой системы «КонсультантПлюс».

3. Зиммерман, Дж. Прямая демократия в Соединенных Штатах Америки: опыт и проблемы / Дж. Зиммерман // Вестник МГУ. Сер. «Право».1991. - № 5. - С. 47-55.

4. Письмо Министерства народного образования РСФСР от 14 нояб. 1989 г. № 17-283-2 «О направлении примерного положения об общественном инспекторе по охране детства в Российской Федерации» // Библиотека нормативно-правовых актов СССР. - Электрон. текстовые дан. - Режим доступа: http://www.libussr.ru/doc_ussr/usr_16018. htm (дата обращения: 03.01.2016). - Загл. с экрана.

5. Постановление Совета Министров СССР от 17 сентября 1986 г. № 1106 «О Всесоюзном музыкальном обществе» // Библиотека нормативно-правовых актов Союза Советских Социалистических Республик. - Электрон. текстовые дан. - Режим доступа: http://www.libussr.ru/doc_ussr/usr_13493. htm (дата обращения: 19.06.2016). - Загл. с экрана.

6. Постановление Совета Министров СССР от 14 февр. 1987 г. № 213 «Об улучшении условий деятельности творческих союзов» // Библиотека нормативно-правовых актов СССР. - Электрон. текстовые дан. - Режим доступа: http://www.libussr.ru/doc_ ussr/usr_13811.htm (дата обращения: 23.01.2016).Загл. с экрана.

7. Постановление Совета Министров СССР от 12 марта 1987 г. № 306 «О финансировании Всесоюзного общества изобретателей и рационализаторов» // Библиотека нормативно-правовых актов СССР - Электрон. текстовые дан. - Режим доступа: http://www.libussr.ru/doc_ussr/usr_13852.htm (дата обращения: 19.06.2016). - Загл. с экрана.

8. Постановление Совета Министров СССР от 23 февраля 1989 г. № 177 «О деятельности на территории СССР советско-американского фонда «Культурная инициатива» // Сайт: Библиотека нормативно-правовых актов СССР. - Электрон. текстовые дан. - Режим доступа: http://www.libussr.ru/doc ussr/usr_15461.htm (дата обращения: 04.02.2016).Загл. с экрана.

9. Постановление Совета Министров СССР от 16 июня 1989 г. № 486 «Об утверждении Положения о деятельности на территории СССР отделения Международной неправительственной организации «Международный центр научной культуры - Всемирная лаборатория» // Библиотека нормативно-правовых актов СССР. - Электрон. текстовые дан. - Режим доступа: http:/www.libussr.ru/doc_ussr/usr_15713.htm (дата обращения: 23.01.2016). - Загл. с экрана.
10. Постановление Совета Министров СССР от 4 мая 1990 г. № 445 «О создании в г. Москве редакционно-издательского комплекса "Милосердие" Советского фонда милосердия и здоровья» // Библиотека нормативно-правовых актов СССР. - Электрон. текстовые дан. - Режим доступа: http://www. libussr.ru/doc_ussr/usr_16533.htm (дата обращения: 03.01.2016). - Загл. с экрана.

11. Постановление Совета Министров СССР от 24 мая 1990 г. № 507 «Вопросы Союза учителей СССР» // Библиотека нормативно-правовых актов СССР. - Электрон. текстовые дан. - Режим доступа: http://www.libussr.ru/doc_ussr/usr_16638.htm (дата обращения: 23.01.2016). - Загл. с экрана;

12. Постановление Совета Министров СССР от 6 июня 1990 г. № 564 «Некоторые вопросы деятельности Союза ветеранов Афганистана» // Библиотека нормативно-правовых актов СССР. - Электрон. текстовые дан. - Режим доступа: http://www. libussr.ru/doc_ussr/usr_16682.htm (дата обращения: 23.01.2016). - Загл. с экрана.

13. Приказ Государственного комитета СССР по народному образованию от 15 авг. 1989 г. № 667 «Об утверждении Положения о совете средней общеобразовательной школы» // Библиотека нормативно-правовых актов СССР. - Электрон. текстовые дан. - Режим доступа: http://www.libussr.ru/doc ussr/usr_15829.htm (дата обращения: 03.01.2016).Загл. с экрана.

14. Приказ Министерства внутренних дел СССР от 30 октября 1985 г. № 209 «Об утверждении Положения о Совете ветеранов в Центральном аппарате МВД СССР» // Библиотека нормативно-правовых актов СССР. - Электрон. текстовые дан. - Режим доступа: http://www.libussr.ru/doc_ussr/usr_12956. htm (дата обращения: 02.02.2016). - Загл. с экрана.

15. Распоряжение Президента СССР от 30 ноября 1991 г. № РП-2934 «О межреспубликанском исследовательском центре частного права» // Библиотека нормативно-правовых актов СССР. - Электрон. текстовые дан. - Режим доступа: http:// www.libussr.ru/doc_ussr/usr_19757.htm (дата обращения: 23.01.2016). - Загл. с экрана.

16. Руденко, Н. В. Институт общего собрания (схода) граждан в современном публичном праве / Н. В. Руденко // Научный ежегодник Института философии и права Уральского отделения Российской академии наук. - 2002. - № 3. - С. 378-413.

17. Указ Президиума Верховного Совета РСФСР от 3 сент. 1985 г. «Положение об общественных сельских, уличных, квартальных комитетах в населенных пунктах РСФСР» // Библиотека нормативно-правовых актов СССР. - Электрон. текстовые дан. - Режим доступа: http://www.libussr.ru/doc ussr/usr_1289.htm (дата обращения: 22.01.2016). Загл. с экрана. 
18. Фортунатов, В. В. Модернизация в России: проект, имитация, задачи / В. В. Фортунатов // Национальная безопасность и стратегическое планирование. - 2016. - № 2-2 (14). - С. 116-120.

19. Халий, И. А. Современные общественные движения: инновационный потенциал российских преобразований в традиционалистской среде / И. А. Халий. М. : Институт социологии РАН, 2007.-300 c.

\section{REFERENCES}

1. Doklad sekretarya gorkoma KPSS tov. L.G. Kaymakchi na gorodskom soveshchanii, posvyashchyennom voprosam sovershenstvovaniya raboty po mestu zhitelstva trudyashchikhsya [Report by Secretary of City Town Committee of the Communal Party of the USSR, Comrade L.G. Kaymakchi at the City Meeting Devoted to the Issues of Work Improvement on the Workers Residence]. Tsentr dokumentatsii noveyshey istorii Rostovskoy oblasti [Center of Documentation of the Contemporary History of the Rostov Region], F. 13, Op. 20, D. 129.

2. Zakon SSSR «Ob obshchestvennykh obyedineniyakh» ot 9 oktyabrya 1990 g. № 1708-1 [The Law of the USSR “About Public Associations" of October 9, 1990 no. 1708-1]. Konsultant-Plyus Website. Available at: http://base.consultant.ru/cons/cgi/online.cgi?req= doc\&base $=$ LAW\&n=1883\&fld $=134 \& d s t=100007,0 \&$ rnd $=0.6527475160961242$. (accessed May 5, 2016).

3. Zimmerman Dzh. Pryamaya demokratiya v Soedinennykh Shtatakh Ameriki: opyt i problemy [Direct Democracy in the United States of America: Experience and Problems]. Vestnik MGU. Ser. "Pravo", 1991, no. 5, pp. 47-55.

4. Pismo Ministerstva narodnogo obrazovaniya RSFSR ot 14 noyabrya 1989 g. № 17-283-2 «O napravlenii primernogo polozheniya ob obshchestvennom inspektore po okhrane detstva v Rossiyskoy Federatsii» [The Letter of the Ministry of National Education of RSFSR of November 14, 1989 no. 17-283-2 "About the Direction of Approximate Provision on the Public Inspector on Child Care in the Russian Federation"]. Sayt: Biblioteka normativno-pravovykh aktov SSSR [Website: Library of Normative Legal Acts of the USSR]. Available at: http://www.libussr.ru/doc_ussr/usr_16018.htm. (accessed March 1, 2016).

5. Postanovlenie Soveta Ministrov SSSR ot 17 sentyabrya 1986 g. № 1106 «O Vsesoyuznom muzykalnom obshchestve» [The Resolution of Council of Ministers of the USSR of September 17, 1986 no. 1106 “About all-Union Musical Society”]. Sayt: Biblioteka normativno-pravovykh aktov SSSR [Website: Library of Normative Legal Acts of the USSR]. Available at: http://www.libussr.ru/doc_ussr/ usr 13493.htm. (accessed June 19, 2016).
6. Postanovlenie Soveta Ministrov SSSR ot 14 fevralya 1987 g. № 213 «Ob uluchshenii usloviy deyatelnosti tvorcheskikh soyuzov» [The Resolution of Council of Ministers of the USSR of February 14, 1987 no. 213 "About Improvement of Conditions of the Creative Unions Activity"]. Sayt: Biblioteka normativno-pravovykh aktov SSSR [Website: Library of Normative Legal Acts of the USSR]. Available at: http://www.libussr.ru/doc ussr/usr 13811.htm. (accessed January 23, 2016).

7. Postanovlenie Soveta Ministrov SSSR ot 12 marta 1987 g. № 306 «O finansirovanii Vsesoyuznogo obshchestva izobretateley i ratsionalizatorov»» [The Resolution of Council of Ministers of the USSR of March 12, 1987 no. 306 "About Financing All-Union Society of Inventors and Innovators"]. Sayt: Biblioteka normativno-pravovykh aktov SSSR [Website: Library of Normative Legal Acts of the USSR]. Available at: http://www.libussr.ru/doc_ussr/ usr 13852.htm. (accessed June 19, 2016).

8. Postanovlenie Soveta Ministrov SSSR ot 23 fevralya 1989 g. № 177 «O deyatelnosti na territorii SSSR sovetsko-amerikanskogo fonda «Kulturnaya initsiativa» [The Resolution of the Council of Ministers of the USSR of February 23, 1989 no. 177 "About the Activity in the Territory of the USSR of the SovietAmerican Fund "Cultural Initiative"]. Sayt: Biblioteka normativno-pravovykh aktov SSSR [Website: Library of Normative Legal Acts of the USSR]. Available at: http://www.libussr.ru/doc_ussr/usr_15461.htm mode. (accessed February 4, 2016).

9. Postanovlenie Soveta Ministrov SSSR ot 16 iyunya 1989 g. № 486 «Ob utverzhdenii Polozheniya o deyatelnosti na territorii SSSR otdeleniya Mezhdunarodnoy nepravitelstvennoy organizatsii «Mezhdunarodnyy tsentr nauchnoy kultury Vsemirnaya laboratoriya» [The Resolution of the Council of Ministers of the USSR of June 16, 1989 no. 486 "About the Adoption of the Provision on Activity of Department of the International Non-Governmental Organization "The International Center of Scientific Culture - the World Laboratory" in the Territory of the USSR]. Sayt: Biblioteka normativno-pravovykh aktov SSSR [Website: Library of Normative Legal Acts of the USSR]. Available at: http://www.libussr.ru/ doc_ussr/usr_15713.htm. (accessed January 23, 2016).

10. Postanovlenie Soveta Ministrov SSSR ot 4 maya 1990 g. № 445 «O sozdanii v g. Moskve redaktsionno-izdatelskogo kompleksa «Miloserdie» Sovetskogo fonda miloserdiya i zdorovya [The Resolution of Council of Ministers of the USSR of May 4, 1990 no. 445 "On Establishment of the Miloserdie Publishing Complex of the Soviet Fund for Charity and Health in Moscow"]. Sayt: Biblioteka normativno-pravovykh aktov SSSR [Website: Library of Normative Legal Acts of the USSR]. Available at: 
http://www.libussr.ru/doc_ussr/usr_16533.htm. (accessed January 3, 2016).

11. Postanovlenie Soveta Ministrov SSSR ot 24 maya 1990 g. № 507 «Voprosy Soyuza uchiteley SSSR» [The Resolution of Council of Ministers of the USSR of May 24, 1990 no. 507 "Issues of the Union of Teachers of the USSR"]. Sayt: Biblioteka normativnopravovykh aktov SSSR [Website: Library of Normative Legal Acts of the USSR]. Available at: http:// www.libussr.ru/doc_ussr/usr_16638.htm. (accessed January 23, 2016).

12. Postanovlenie Soveta Ministrov SSSR ot 6 iyunya 1990 g. № 564 «Nekotorye voprosy deyatelnosti Soyuza veteranov Afganistana» [The Resolution of Council of Ministers of the USSR of June 6, 1990 no. 564 "Some Issues of Activity of the Union of Veterans of Afghanistan"]. Sayt: Biblioteka normativno-pravovykh aktov SSSR [Website: Library of Normative Legal Acts of the USSR]. Available at: http://www.libussr.ru/doc_ussr/usr_16682.htm mode. (accessed January 23, 2016).

13. Prikaz Gosudarstvennogo komiteta SSSR po narodnomu obrazovaniyu ot 15 avgusta 1989 g. № 667 «Ob utverzhdenii Polozheniya o sovete sredney obshcheobrazovatel'noy shkoly» [The Order of the State Committee of the USSR on National Education of August 15, 1989 no. 667 "About the Adoption of the Provision on Council of High Comprehensive School"]. Sayt: Biblioteka normativno-pravovykh aktov SSSR [Website: Library of Normative Legal Acts of the USSR]. Available at: http://www.libussr.ru/ doc_ussr/usr_15829.htm. (accessed January 3, 2016).

14. Prikaz Ministerstva vnutrennikh del SSSR ot 30 oktyabrya 1985 g. № 209 «Ob utverzhdenii Polozheniya o Sovete veteranov v Tsentralnom apparate MVD SSSR» [The Order of the Ministry of Internal Affairs of the USSR of October 30, 1985 no. 209 "About the Adoption of the Provision on Council of veterans in Central Office of the Ministry of Internal Affairs of the USSR']. Sayt: Biblioteka normativnopravovykh aktov SSSR [Website: Library of Normative
Legal Acts of the USSR]. Available at: http:// www.libussr.ru/doc_ussr/usr_12956.htm. (accessed February 2, 2016).

15. Rasporyazhenie Prezidenta SSSR ot 30 noyabrya 1991 g. № RP-2934 «O mezhrespublikanskom issledovatelskom tsentre chastnogo prava» [The Order of the President of the USSR of November 30, 1991 no. RP-2934 "About the Interrepublican Research Center of Private Law"]. Sayt: Biblioteka normativnopravovykh aktov SSSR [Website: Library of Normative Legal Acts of the USSR]. Available at: http:// www.libussr.ru/doc_ussr/usr_19757.htm. (accessed January 23, 2016).

16. Rudenko N.V. Institut obshchego sobraniya (skhoda) grazhdan v sovremennom publichnom prave [Institute of a General Meeting (Descent) of Citizens in Modern Public Law]. Nauchnyy ezhegodnik Instituta filosofii i prava Uralskogo otdeleniya Rossiyskoy akademii nauk, 2002, no. 3, pp. 378-413.

17. Ukaz Prezidiuma Verkhovnogo Soveta RSFSR ot 3 sentyabrya 1985 g. «Polozhenie ob obshchestvennykh selskikh, ulichnykh, kvartalnykh komitetakh v naselyennykh punktakh RSFSR» [Decree of Presidium of the Supreme Council of RSFSR of September 3, 1985 "Provision on Public Rural, Street, Quarter Committees in Settlements of RSFSR"]. Sayt: Biblioteka normativno-pravovykh aktov SSSR [Website: Library of Normative Legal Acts of the USSR]. Available at: http://www.libussr.ru/doc_ussr/ usr_12893.htm. (accessed January 22, 2016).

18. Fortunatov V.V. Modernizatsiya v Rossii: proekt, imitatsiya, zadachi [Modernization in Russia: Project, Imitation, Tasks]. Natsionalnaya bezopasnost i strategicheskoe planirovanie, 2016, no. 2-2 (14), pp. 116-120.

19. Khaliy I.A. Sovremennye obshchestvennye dvizheniya: innovatsionnyy potentsial rossiyskikh preobrazovaniy $v$ traditsionalistskoy srede [Modern Social Movements: Innovative Potential of the Russian Transformations in the Traditionalist Environment]. Moscow, Institut sotsiologii RAN, 2007. 300 p.

\section{Information About the Author}

Elena N. Shuyakova, Candidate of Sciences (History), Chairman of the Board of the "Russian community" regional public organization for the protection and realization of civil, economic and social rights, Zonalnyy Lane, 28C, 1, 344023 Rostov-on-Don, Russian Federation, 1shuyakova@mail.ru.

\section{Информация об авторе}

Елена Николаевна Шуякова, кандидат исторических наук, председатель Правления Региональной общественной организации по защите и реализации гражданских, экономических и социальных прав «Русская община», пер. Зональный 28С, 1, 344023 г. Ростов-на-Дону, Российская Федерация, 1shuyakova@mail.ru. 